\title{
The Evaluation of Health-Care Associated Infections In a Tertiary Intensive Care Unit
}

\section{Üçüncü Basamak Bir Yoğun Bakımda Görülen Sağlık Bakımı İlişkili Enfeksiyonların Değerlendirilmesi}

\begin{abstract}
Fatma Çölkesen', (1) Fatih Çölkesen²
${ }^{1}$ Health Sciences University, Konya Training and Research Hospital, Clinic Of Infectious Diseases and Clinical Microbiology, Konya, Turkey ${ }^{2}$ Necmettin Erbakan University, Meram Medical Faculty, Deparment of Internal Medicine, Division of Clinical Immunology and Allergy, Konya, Turkey
\end{abstract}

\begin{abstract}
Aim: In this study, we aimed to determine the epidemiological characteristics of infections detected in a tertiary ICU of our hospital and to evaluate the transmission routes.

Material and Method: A total of 1278 patients who were followed up in the ICU for two years were analyzed retrospectively. Health-care associated infection (HAl) diagnoses were evaluated according to the "Centers for Disease Control and Prevention (CDC)" criteria.

Results: Fifty-seven of the patients who were followed up were diagnosed with $\mathrm{HAl}$, and 54 pathogens were detected. The rate of $\mathrm{HAl}$ development among patients hospitalized in the ICU was $5.24 \%$. In this unit; mechanical ventilator day was 3483 , rate of ventilator utilization was $51 \%$, speed of VAP was 0.86 , UC day was 6734 , rate of UC utilization was $100 \%$, speed of CR-UTI was 0.89 , CVC day was 4327 , rate of CVC utilization was $63 \%$, speed of CVCR$\mathrm{BSI}$ was determined as 3.93 . Pneumonia with specific laboratory findings was the most common infection in patients with HAI (33.4\%). Other infections of the lower respiratory tract (31.6\%), CVCR- BSI (14\%), CR-UTI (7\%), VAP (5.2\%), clinically defined pneumonia (5.2\%),soft tissue infection (1.8\%) and laboratory-proven BSI (1.8\%) respectively, were followed. Eleven different microorganisms were determined as the pathogens of HAI. The bacteriological profile causing HAl in the study, Gram-negative and Grampositive pathogens were $87,1 \%$ and $12.9 \%$, respectively. Acinetobacter baumanni was the most common pathogen (51.9\%). Other pathogens were Pseudomonas aeruginosa (11.1\%), Klebsiella pneumoniae $(9.3 \%)$, Staphylococcus aureus (5.6\%), Escherichia coli (5.6\%), Stenotrophomonas maltophila (5.6\%), Enterococcus faecium (3.7\%), Acinetobacter Iwoffi (1.9\%), Enterococcus faecalis (1,9\%), Coagulase-negative staphylococcus (1.9\%) and Enterobacter cloacae (1.9\%).

Conclusion: Each unit should determine its patient profile, flora and resistance patterns by conducting surveillance studies and plan treatment strategies accordingly.
\end{abstract}

Keywords: Health-care associated infection, intensive care unit, surveillance.
Öz

Amaç: Bu çalışma ile hastanemizin üçüncü basamak biryoğun bakım ünitesinde (YBÜ) tespit edilen sağlık bakımı ilişkili enfeksiyonların (SBIE) epidemiyolojik özelliklerinin belirlenmesi ve bulaş yolları ile ilgili değerlendirilme yapılması amaçlanmıştır.

Gereç ve Yöntem: YBÜ'de iki yıl boyunca takip edilen toplam 1278 hastanın takipleri retrospektif olarak incelendi. SBIE tanıı "Hastalık Kontrol ve Önleme Merkezleri (CDC)" kriterlerine göre değerlendirildi.

Bulgular: Takip edilen hastaların 57 tanesinde SBIE tespit edildi ve 54 etken saptandı. Yoğun bakıma yatııılan hastalar arasında SBIE geliş̧me oranı \%5,24 olarak hesaplandı. Bu ünitede; mekanik ventilatör kullanım günü 3483, ventilatör kullanım oranı \%51, ViP hızı 0,86, ÜK kullanım günü 6734, ÜK kullanım oranı \%100, Ki-ÜSE hızı 0,89, SVK kullanım günü 4327, SVK kullanım oranı\%63, SVKI-KDE hızı 3,93 olarak belirlendi. SBIE görülen hastalarda en sık spesifik laboratuvar bulguları olan pnömoni tespit edildi $(\% 33,4)$. Bunu sırasıyla alt solunum yollarının diğer enfeksiyonları $(\% 31,6)$, SVKI-KDE (\%14), Ki-ÜSE (\%7), ViP $(\% 5,2)$, klinik olarak tanımlanmış pnömoni $(\% 5,2)$, yumuşak doku enfeksiyonu (YDE) $(\% 1,8)$ ve laboratuvar tarafından kanıtlanmış KDE $(\% 1,8)$ izledi. SBIE etkeni olarak 11 farklı mikroorganizma saptandı. Tüm SBIE patojen dağılımına bakıldığında \%87,1 oranında Gram negatif, \%12,9 Gram pozitif patojen görüldü. Acinetobacter baumanni en sık saptanan patojendi $(\% 51,9)$. Bunu sırasıyla Psödomonas aeruginosa $(\% 11,1)$, Klebsiella pneumoniae $(\% 9,3)$, Staphylococcus aureus $(\% 5,6)$, Escherichia coli $(\% 5,6)$, Stenotrophomonas maltophila $(\% 5,6)$, Enterococcus faecium $(\% 3,7)$, Acinetobacter Iwoffi $(\% 1,9)$, Enterococcus faecalis $(1,9 \%)$, Koagülaz-negatif stafilokok $(\% 1,9)$ ve Enterobacter cloacae $(\% 1,9)$ izledi.

Sonuç: Her ünite kendi hasta profilini, florasını ve bunların direnç paternlerin sürveyans çalışmaları yaparak saptamalı ve tedavi stratejilerini buna göre planlamalıdır.

Anahtar Sözcükler: Sağılı bakımı ilişkili enfeksiyon, yoğun bakım ünitesi, sürveyans.

Corresponding (IIletişim): Fatma Çölkesen, Health Sciences University, Konya Training and Research Hospital, Clinic Of Infectious Diseases and Clinical Microbiology, Konya, Turkey

E-mail (E-posta): fatma.derin@hotmail.com

Received (Geliş Tarihi): 20.02.2020 Accepted (Kabul Tarihi): 14.07.2020 


\section{INTRODUCTION}

Health-care associated infection (HAl) are still an important health problem in the world despite the precautions taken. These infections cause an increase in morbidity, mortality and treatment costs depending on the length of hospital stay. ${ }^{[1]}$ Patients hospitalized in intensive care units (ICU); are the group with the most severe clinical picture, the longest hospital stay, the most frequently used invasive procedures and the use of broad-spectrum antibiotics. ${ }^{[2]}$ Approximately $20-25 \%$ of all HAls are seen in the ICU. ${ }^{[3]}$ Urinary tract infection (UTI), catheter infection, ventilator-associated pneumonia (VAP) and surgical site infection (SSI) are among the most common infections in patients followed up in these units. ${ }^{[4]}$ Resistant microorganisms are generally responsible for infections that develop in the ICU. This causes important problems in treatment and increases mortality and morbidity. Control of these infections is possible by monitoring the surveillance results in each hospital, comparing these results with the infection rates of other hospitals and taking effective infection control preventions. ${ }^{[5]}$ The detection of common infection factors in the hospital through surveillance studies provides an appropriate and successful treatment planning. Besides, it is essential to identify common infectious agents to perform empirical treatment planning successfully. In this study, we aimed to determine the epidemiological characteristics of infections detected in a tertiary ICU of our hospital and to evaluate the source of contaminations.

\section{MATERIALS AND METHODS}

The study was approved by the local ethics committee of University of Health Sciences, Konya Training and Research Hospital, with the 06.02.2020/35-32 ID number. A total of 1278 patients hospitalized in Konya Training and Research Hospital 3rd level ICU between the dates of 01.10.2017-30.09.2019 were retrospectively followed up with patient-based active surveillance methods in terms of nosocomial infections. In this period, a total of $57 \mathrm{HAl}$ cases were diagnosed. Health-care associated infection diagnoses were evaluated according to the "Centers for Disease Control and Prevention (CDC)" criteria. The study was carried out in accordance with the Helsinki Declaration Principles. The patients included in the study were over 18 years old. Culture samples were taken according to the physical examination findings of the patients. When the fever was over $38^{\circ} \mathrm{C}$, blood cultures were repeated. According to the patient's examination findings, throat culture, blood and catheter culture, urine culture, tracheal aspirate culture, bronchoalveolar lavage culture were taken. While evaluating the culture results, physical examination findings, biochemical and hematological examination results, radiological imaging methods were taken into consideration.

\section{Invasive device-associated hospital infections rates;}

- Ventilator-associated pneumonia (VAP) rate=VAP number / ventilator day $\times 100$,
- Catheter-related urinary tract infection (CR-UTI) rate=CRUTI number / urinary-catheter (UC) day x 100,

- Central venous catheter (CVC) -related bloodstream infection (BSI) rate=CVCR-BSI number / CVC day was calculated with the formula $\times 100$.

\section{Statistical analysis}

SPSS version 20.0 (IBM SPSS Statistics 20.0) was used for data evaluation and analysis. Variables are expressed as mean \pm standard deviation, and categorical variables as numbers and percentages.

\section{RESULTS}

A total of 1278 patients who were followed up in the ICU for two years were analyzed retrospectively. HAls were detected in 57 of these patients. The patients who were diagnosed with HAl, 35 (61.4\%) were male, and 22 (38.6\%) were female. Fiftyseven of the patients who were followed up were diagnosed with $\mathrm{HAl}$, and 54 pathogens were detected. The diagnosis of hospitalization for patients diagnosed with HAl is shown in Table 1.

\begin{tabular}{lcc} 
Table 1. Distribution of hospitalization diagnosis & & \\
Hospitalization Diagnosis & $\mathbf{n}$ & $\%$ \\
\hline Traffic accident & 14 & 24.5 \\
Cerebrovascular disease & 14 & 24.5 \\
Renal failure & 10 & 17.5 \\
Chronic obstructive pulmonary disease & 4 & 7 \\
Subarachnoid hemorrhage & 4 & 7 \\
Toxicity & 3 & 5.4 \\
Electric shock & 2 & 3.5 \\
Fall & 2 & 3.5 \\
Cardiac arrest & 2 & 3.5 \\
Malignancy & 1 & 1.8 \\
Pneumothorax & 1 & 1.8 \\
Total & 57 & 100 \\
\hline
\end{tabular}

In this unit; mechanical ventilator day was 3483 , rate of ventilator utilization was $51 \%$, speed of VAP was 0.86 , UC day was 6734 , rate of UC utilization was $100 \%$, speed of CR-UTI was 0.89 , CVC day was 4327 , rate of CVC utilization was $63 \%$, speed of CVCR- BSI was determined as 3.93. Two-year invasive device utilization ratio and rates of infection in ICU are given in Table 2.

\begin{tabular}{lccccc}
\hline Table 2. Device utilization ratio and deviceassociated infection rates & $\begin{array}{c}\text { Utilization } \\
\text { day }\end{array}$ & $\begin{array}{c}\text { Utilization } \\
\text { ratio }\end{array}$ & $\begin{array}{c}\text { Infection } \\
\text { number }\end{array}$ & $\begin{array}{c}\text { Infection } \\
\text { rate }\end{array}$ \\
\hline $\begin{array}{l}\text { Central venous } \\
\text { catheter }\end{array}$ & 4327 & 0.63 & $\begin{array}{c}\text { CVCR- } \\
\text { BSI }\end{array}$ & 8 & 3.93 \\
$\begin{array}{l}\text { Urinary- } \\
\text { catheter }\end{array}$ & 6734 & 0.89 & CR-UTI & 4 & 0.89 \\
$\begin{array}{l}\text { Mechanical } \\
\text { ventilator }\end{array}$ & 3483 & 0.51 & VAP & 3 & 0.86 \\
\hline
\end{tabular}


The rate of HAl development among patients hospitalized in the ICU was $5.24 \%$. Pneumonia with specific laboratory findings was the most common infection in patients with $\mathrm{HAl}$ (33.4\%). Other infections of the lower respiratory tract (31.6\%), CVCR- BSI (14\%), CR-UTI (7\%), VAP (5.2\%), clinically defined pneumonia (5.2\%), soft tissue infection (1.8\%) and laboratoryproven BSI (1.8\%) respectively, were followed (Figure 1).

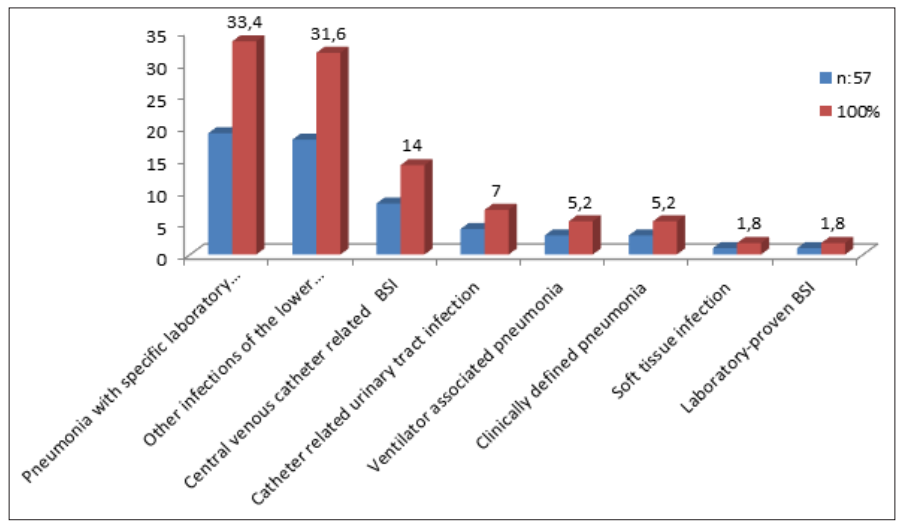

Figure 1. Distribution of health-care associated infections

Eleven different microorganisms were determined as the pathogens of HAI. The bacteriological profile causing HAI in the study, Gram-negative and Gram-positive pathogens were $87,1 \%$ and $12,9 \%$, respectively. Acinetobacter baumanni was the most common pathogen (51.9\%). The distribution of other pathogens is shown in Figure 2.

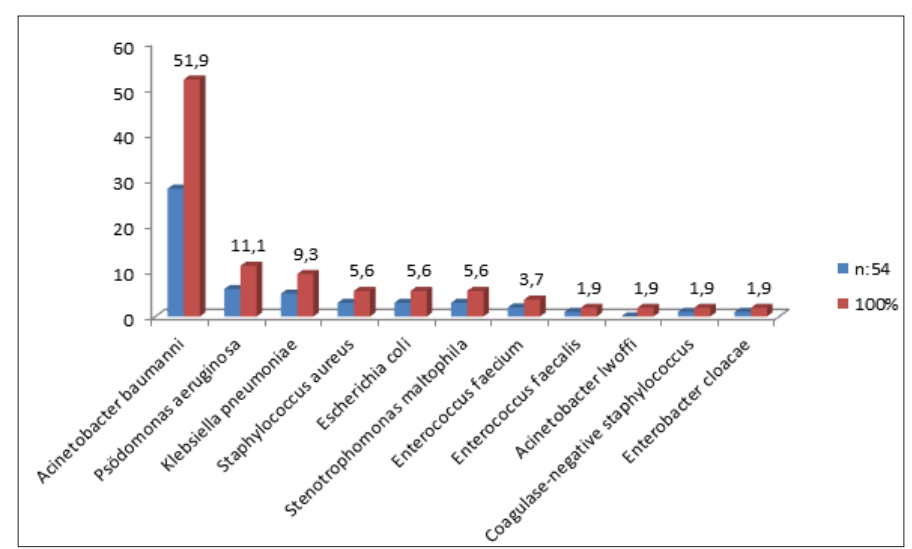

Figure 2. Distribution of isolated pathogens

Pneumonia with specific laboratory findings was caused by A.baumanni, K.pneumoniae, P.aeruginosa and E.cloacae; $73.6 \%, 10.6 \%, 10.6 \%, 5.2 \%$, respectively. A.baumanni, S.aureus, K.pneumoniae, P.aeruginosa and E.coli, were caused to other infections of the lower respiratory tract, were determined to be $55.5 \%, 16.6 \%, 11.2 \%, 11.2 \%$ and $5.5 \%$, respectively. In $25 \%, 25 \%, 25 \%, 12.5 \%, 12.5 \%$ CVCR- BSI, the pathogens were A.baumanni, P.aeruginosa, S.maltophila, E.faecalis and A.Iwoffi, respectively. $50 \%$ of catheter-associated UTI were from E.faecium, 25\% from E.coli and 25\% from K.pneumoniae.
A.baumanni in $66.7 \%$ and S.maltophila in $33.3 \%$ of the VAP were detected. The pathogen in soft tissue infection was E.coli $(100 \%)$, and the pathogen in laboratory-proven BSI.

\section{DISCUSSION}

The patients in ICU compared to the patients in the general hospital population have more comorbid diseases and more acute severe physiological disorders, so they are under relative immunosuppression. Invasive interventions such as intravenous catheters, endotracheal tubes, and urinary catheters reduce host resistance against infections. Therefore, more diseases and infections are encountered in ICU than in other hospital units. ${ }^{[6,7]}$

According to 2017 Turkey's National Nosocomial Infections Surveillance Network (NNISN); a summary in all tertiary health center intensive care unit-acquired infections data was; in Anesthesiology ICUs rate of ventilator utilization was $62 \%$, speed of VAP was 6.8 , rate of ventilator utilization Internal Medicine ICUs was 31\%, the speed of VAP was 5.5, the rate of ventilator utilization was $40 \%$ and the speed of VAP was 3.5 in the Chest Diseases ICUs. ${ }^{[8]}$ The rate of mechanical ventilator utilization in our ICU is similar to the other tertiary care centers ICUs average, but our VAP speed is lower than other ICUs. According to NNISN data, the rate of UC utilization in Anesthesia and Reanimation ICUs was $97 \%$, the speed of CR-UTI was 2.5, the rate of UC utilization in Internal Diseases ICUs was $91 \%$, the speed of CR-UTI was 2.2 and in the Chest Diseases ICUs the rate of UC utilization was reported to be $83 \%$, and the speed of CR-UTI was $1 .^{[8]}$ In our study, our rate of UC utilization was higher than other NNISN data, but our speed of CR-UTI was lower. Although we have a high rate of insertion of UC in our ICU, it has been thought that the necessary care has been given to catheter care in our unit. To reduce our urinary catheter insertion rate, unnecessary catheterization should be avoided.

According to NNISN data, the rate of CVC utilization in the Anesthesia and Reanimation ICUs was $61 \%$, the speed of CVCR-BSI was $4.5 \%$, the rate of CVC utilization in the Internal Diseases ICUs was $43 \%$, the CVCR-BSI speed was 4.5 , the rate of CVC utilization in the Emergency ICUs was $42 \%$, the CVCRBSI speed was reported as 6.7. ${ }^{[8]}$ In our study, the rate of CVC utilization was 63\%, and the speed of CVCR-BSI was 3.93 . Our CVC utilization rate was slightly higher, but the speed of CVCR-BSI was lower than the NNISN data. It was thought that CVC care was performed in accordance with the infection prevention rules in our unit.

In a study by Karahocagil et al. ${ }^{[9]}$ investigating HAl incidences, $\mathrm{HAl}$ rates have been shown to be $5 \%$ in pediatric ICU, $5.6 \%$ in chest diseases ICU and $18.3 \%$ in Anesthesia and Reanimation ICU. In the study carried out by Dağlı et al. ${ }^{[10]}$ in ICUs in a university hospital, the rate of HAI was found to be $49.7 \%$. In the study conducted by İnan et al. ${ }^{[1]]}$ it was shown that the infection rates in all ICUs varied between $1.6 \%$ and $47.4 \%$. In our study, the rate of HAI development was calculated as $5.24 \%$ 
among the patients admitted to ICU, and it was seen that the infection rates in our unit were lower than the literature data of previous years. It was thought that increasing technical possibilities, increasing the use of more antibiotic groups, and increasing awareness of healthcare professionals about handwashing and infection may be effective in this decrease in $\mathrm{HAl}$ rates.

The most common infections in ICUs are UTI, BSI, and pneumonia. ${ }^{[12]}$ The most common three infections were pneumonia, UTI and catheter-related infection (CRI) in the study conducted by Pişkin et al. ${ }^{[13]}$ In the study conducted by Akın et al. ${ }^{[14]}$ in the Anesthesia ICU, it was stated that pneumonia, BSI and UTI are the most common HAIs. In the study in which Şahin et al. ${ }^{[15]}$ evaluated HAls in the ICU, the most common infections were pneumonia, UTI, and BSI. In the study conducted by Kaya et al. ${ }^{[16]}$ in a tertiary ICU, BSI, UTI, and CRI were reported as the most common HAls. In our study, similar to many studies conducted in ICU, the most common distribution of infections were pneumonia, CVCR-BSI and CRUTI.

Health-care associated infection factors that develop in the ICU can vary from hospital to hospital, as well as may vary over time in the same unit. ${ }^{[17]}$ In studies conducted in our country, the most commonly isolated pathogenic microorganisms were in ICUs; S.aureus (19-37\%), P.aeruginosa (17-32\%), E.coli, Klebsiella spp. and Acinetobacter spp. ${ }^{[18]}$ The most frequent $\mathrm{HAl}$ factor was reported as Acinetobacter, Pseudomonas and Enterobacter in the study conducted by Tüfek et al. ${ }^{[19]}$ In the study of Dikici et al. ${ }^{[20]}$ the three most frequently isolated pathogens were A.baumannii, S.aureus, and E.coli, respectively. In the study of Erdinç et al. ${ }^{[21]}$ it was stated that the most frequently isolated microorganisms were E.coli, K.pneumoniae, Enterococcus species and S.aureus. In a prevalence study (EPIC II) in which ICUs were examined and 1265 ICUs from 75 countries participated, it was reported that $62 \%$ of positive isolates were Gram-negative, $47 \%$ were Gram-positive bacteria and $19 \%$ were fungi. Similar to our study in many studies conducted in our country, Gram-negative bacteria appear as the most common factor. In our study, 87,1\% Gramnegative and $12.9 \%$ Gram-positive pathogens were observed as the factors of HAl. The three most common pathogens were A.baumanii, P.aeruginosa and K.pneumoniae. When the distribution of infection agents according to specific regions is examined, it is observed that Gram-negative bacteria are more isolated in CR-UTI, VAP and Gram-positive bacteria in BSI. In the study conducted by Motor et al. ${ }^{[22]}$ A.baumannii in VAP, E.coli in CR-UTI and Gram-positive cocci in BSI were identified as infection agents. In the study of Öktem et al. ${ }^{[23]}$ Gramnegative bacteria, especially Acinetobacter spp., P.aeruginosa, K.pneumoniae and E.coli, are frequently isolated as agents, while gram-positive bacteria, coagulase-negative in the bloodstream and surgical site infections. Staphylococci (CNS), S.aureus and Enterococcus species were seen as causative agents. In our study, A.baumanni was found to be the most common pathogen in pneumonia with specific laboratory findings, other infections of the lower respiratory tract and VAP (73.6\%, 55.5\%, 66.7\%, respectively). In the CVCR-BSI, the three most common pathogens are A.baumanni, P.aeruginosa, and S.maltophila ( $25 \%$ incidence of all ). The most common pathogen was E.faecium (50\%) in CR-UTI, the most common pathogen was E.coli (100\%) in soft tissue infection, and the most common pathogen in laboratory-proven BSI was Coagulase-negative staphylococcus (100\%). In our ICU, Acinetobacter appears as an essential problem. Reasons for this include inappropriate antibiotic use, unnecessary longterm prophylaxis, antibiotic revision according to culture results, and failure to follow infection control measures to the required extent.

\section{CONCLUSION}

HAls are significant cause of morbidity, mortality, and cost increase in our country as well as all over the world. Therefore, the incidence of HAl will be greatly reduced by avoiding unnecessary invasive procedures in patients, removing invasive catheters as soon as possible, paying attention to aseptic practices, taking infection control measures, preventing inappropriate antibiotic use, and taking isolation measures. Besides, each unit should determine its patient profile, flora, and resistance patterns by conducting surveillance studies and plan treatment strategies accordingly.

\section{ETHICAL DECLARATIONS}

Ethics Committee Approval: The study was approved by the local ethics committee of University of Health Sciences, Konya Training and Research Hospital, with the 06.02.2020/35-32 ID number.

Informed Consent: Because the study was designed retrospectively, no written informed consent form was obtained from patients.

Referee Evaluation Process: Externally peer-reviewed. Conflict of Interest Statement: The authors have no conflicts of interest to declare.

Financial Disclosure: The authors declared that this study has received no financial support.

Author Contributions: All of the authors declare that they have all participated in the design, execution, and analysis of the paper, and that they have approved the final version.

\section{REFERENCES}

1. Eren F, Öngün G, Ural O, Öztürk Ş. Nöroloji yoğun bakım ünitesinde bir yıllık hastane enfeksiyonu oranları: Patojenik ve klinik değerlendirme. Türk Nöroloji Dergisi. 2017;23(4):205-10.

2. Çetin Ç, Yalçın A, Turgut H, Kaleli I, Orhan N. Pamukkale Üniversitesi Tıp Fakültesi Hastanesi'nde hastane infeksiyonları. Hastane İnfeksiyonları Dergisi. 1999;3(3):161-4.

3. Trilla A. Epidemiology of nosocomial infections in adult intensive care units. Intensive Care Medicine. 1994;20(3):S1-S4.

4. Kappstein I, Daschner FD. Nosocomial infections in intensive care units. Current Opinion in Infectious Diseases. 1990;3(4):509-12. 
5. Taşbakan M, Sipahi O, Pullukçu H, Aydemir Ş, Tünger A, Yurtseven T, et al. Nöroşirürji yoğun bakım ünitesinde görülen hastane enfeksiyonlarının değerlendirilmesi. Ege Tıp Dergisi. 2006;45(2):127-30.

6. Hynes-Gay P, Lalla P, Leo M, Merrill-Bell A, Nicholson M, Villaruel E. Understanding sepsis: from SIRS to septic shock. Dynamics (Pembroke, Ont). 2002;13(1):17-20, 2-4; quiz 5-6.

7. Spencer R. Epidemiology of infection in ICUs. Intensive care medicine. 1994;20(4):S2-S6.

8. Ulusal hastane enfeksiyonları sürveyans ağı (UHESA) raporu özet veri, 2017. 2017 [Available from: https://hsgm.saglik.gov.tr/depo/Duyurular/ Surveyans Ağı Özet Raporu 2017.

9. Karahocagil MK, Yaman G, Göktaş U, Sünnetçioğlu M, Çıkman A, Bilici A, et al. Hastane enfeksiyon etkenlerinin ve direnç profillerinin belirlenmesi. Van Tıp Dergisi. 2011;18 (1):27-32.

10. Dağlı O, Namıduru M. Geçmişten Bir Analiz; Gaziantep Üniversitesi Tıp Fakültesi Hastanesi yoğun bakım ünitelerinde nozokomiyal enfeksiyonların irdelenmesi ve enfeksiyon risk faktörlerinin belirlenmesi. Sağlık Akademisi Kastamonu.3(3):38-62.

11. Innan D, Saba R, Keskin S, Öğünç D, Çiftçi C, Günseren F, et al. Akdeniz Üniversitesi Hastanesi yoğun bakım ünitelerinde hastane infeksiyonları. Yoğun Bakım Dergisi. 2002;2(2):129-35.

12. Rosenthal VD, Maki DG, Salomao R, Moreno CA, Mehta Y, Higuera F, et al. Device-associated nosocomial infections in 55 intensive care units of 8 developing countries. Annals of internal medicine. 2006;145(8):582-91.

13.Pişkin $N$, Tütüncü $E$, Aydemir $H$, Yalçı $A$, Gürbüz $Y$, Türkyılmaz R. Reanimasyon yoğun bakım ünitemizde görülen nozokomiyal infeksiyonlar ve infeksiyon risk faktörleri. Hastane İnfeksiyonları Dergisi. 2006;10:236-43.

14. Akın A, Esmaoğlu Çoruh A, Alp E, Canpolat D. Anestezi yoğun bakım ünitesinde beş yıl içerisinde gelişen nozokomiyal enfeksiyonlar ve antibiyotik direncinin değerlendirilmesi. Erciyes Tıp Derg. 2011;33(1):7-16.

15. Şahin AR, Yıldız BT, Aktemur A, Topal B, Nazik S, Ateş S. Bir üniversite hastanesi noroloji yoğun bakım ünitesinde gelişen enfeksiyonların değerlendirilmesi. Çağdaş Tıp Dergisi. 2019;9(1):43-7.

16. Kaya S, Öksüz H, Şenoğlu N, Doğan Z, Yıldız H. Kahramanmaraş Sütçü Imam Üniversitesi Tıp Fakültesi Araştırma Hastanesi Anesteziyoloji ve Reanimasyon Kliniğinde nozokomiyal infeksiyonlarin surveyansi. Eurasian J Med. 2007;39(2):103-8.

17. Yılmaz N, Köse Ş, Ağuş N, Ece G, Akkoçlu G, Kıraklı C. Yoğun bakım ünitesinde yatan hastaların kan kültürlerinde üreyen mikroorganizmalar, antibiyotik duyarlılıkları ve nozokomiyal bakteriyemi etkenleri. Ankem Derg. 2010;24(1):12-9.

18. Saltoğlu N, Öztürk C, Taşova $Y$, İncecik Ş, Paydaş S, Dündar İ. Yoğun bakım ünitelerinde infeksiyon nedeniyle izlenen hastalarda etkenler, risk faktörleri, antibiyotik direnci ve prognozun değerlendirilmesi. Flora. 2000;5(4):229-37.

19. Tüfek A, Tekin R, Dal T, Tokgöz O, Doğan E, Kavak GÖ, et al. Reanimasyon ünitesinde on yıllık sürede gelişen hastane enfeksiyonlarının değerlendirilmesi ve literatürün gözden geçirilmesi. 2012.

20. Dikici N, Korkmaz F, Dağlı ş, Genç Ö, Ural G. Konya Numune Hastanesi yoğun bakım ünitelerinde izlenen hastane infeksiyonlari: üç yıllık deneyim. Infeks Derg. 2009;23(4):163-7.

21. Vincent J-L, Rello J, Marshall J, Silva E, Anzueto A, Martin CD, et al. International study of the prevalence and outcomes of infection in intensive care units. Jama. 2009;302(21):2323-9.

22. Motor VK, Evirgen Ö, Yula E, Erden EŞ, Ocak S, Önlen Y. Mustafa Kemal Üniversitesi Tıp Fakültesi yoğun bakım ünitesi'nde 2011 yılında sağlık hizmeti ile ilişkili infeksiyonların değerlendirilmesi. Ankem Derg. 2012;26(3):137-42.

23. Öktem M, Gülay Z, Ercan H, Biçmen M, Yuluğ N. Yoğun bakım ünitelerinden soyutlanan mikroorganizmalar ve antibiyotik duyarlılıkları. İnfeksiyon Dergisi. 2001;15(1):61-6. 